\title{
Is There a State Crisis in Sweden?
}

\author{
John H. S. Åberg ${ }^{1}$ \\ Published online: 28 January 2019 \\ (C) The Author(s) 2019
}

\begin{abstract}
Is Sweden a failed state in the making or a paradise on earth? Neither. Sweden is a functioning democracy but it faces serious challenges. This article attempts to make sense of them. It considers issues of law and order and the emergence of parallel structures of power. It shows that Sweden, following an unprecedented wave of immigration, is experiencing an ongoing struggle to define the nation.
\end{abstract}

Keywords Sweden $\cdot$ Nationalism $\cdot$ Crisis $\cdot$ Law and order $\cdot$ Immigration

You know the narrative: Something is terribly wrong in Sweden. The progressive Scandinavian welfare state is crumbling. Right-wing influencers, YouTube reporters, Donald Trump, and RT are all warning about rampant social problems that seem to be tearing the country apart. Even Swedish politicians and commentators - among the Left and the Right alike - seem to agree. If we are to believe some of their rhetoric, Sweden is a failed state in the making.

Yet according to a number of indicators Sweden seems to enjoy the fruits of overwhelming success. In 2018, Sweden ranked number seven in the Human Development Index, and in 2017, Sweden ranked number six in the Good Country Index. While the Fragile State Index ranked South Sudan as number 1 , Sweden ranked 170 among 178 countries. To continue, and with the risk of belaboring the point, the Global Competitiveness Index (2018), the Country Brand Index (2015), the Happiness Index (2018), and the Social Progress Index (2017) reveal that Sweden ranks number 7, 4, 9, and 8 respectively. In other words, Sweden is among the world elite of high performing countries. Swedish government officials often use this fact as a counterpunch against critics who dear to smear Sweden's beautiful image.

How to make sense of this paradox: a country that is both successful and in crisis? In what follows, I will try to explain it, focusing on the problems that Sweden currently faces.

John H. S. Åberg

john.hs.aberg@gmail.com

1 Faculty of Culture and Society, Department of Global Political Studies (GPS), Malmö University, Nordenskiöldsgatan 1, 211 19 Malmö, Sweden

\section{Crime and the Threat to Law and Order}

Sweden has lost control of its territory. At least certain parts of it, if we are to believe official reports from the Swedish Police. Every Swedish police region work with so-called area documents that evaluate different geographic areas according to the following four criteria: residents' proclivity to participate in the legal process; the ability of the police to carry out its duties; the existence of parallel social structures; and the presence of extremism, primarily violent Islamist extremism. Areas that meet all four criteria are deemed "specifically vulnerable", whereas areas that meet parts of the criteria are considered "vulnerable". As of 2017, according to the Swedish Police report Vulnerable Areas - Social order, criminal structure and challenges for the police, there are 61 so-called "vulnerable" areas in Sweden, out of which 23 are considered "specifically vulnerable."1

According to the Swedish Police, a "vulnerable" area is characterized by low socioeconomic status and a high degree of immigrant residents. In this type of area, "criminals have an impact on the local community," an impact either in the form of direct action such as extortion and threats or through indirect action such as public drug sales and public acts of violence. Residents in vulnerable areas are reported to experience insecurity, which in turn affects their trust in the Swedish legal institutions and hence their reduced proclivity to report crimes. In areas deemed "specifically vulnerable," the Swedish Police report stresses the existence of a "general

\footnotetext{
${ }^{1}$ Polismyndigheten, 2017, Utsatta områden - Social ordning, kriminell struktur och utmaningar för polisen [Vulnerable Areas - Social order, criminal structure and challenges for the police], https://polisen.se/siteassets/ dokument/ovriga rapporter/utsatta-omraden-social-ordning-kriminellstruktur-och-utmaningar-for-polisen-2017.pdf (accessed 17 Aug. 2018).
} 
disinclination to participate in lawsuits," that threats are more often "systematic," and that it is "difficult or almost impossible for the police to fulfill its duties." The report also states that the opportunity to conduct business in specifically vulnerable areas is "many times limited" and business owners view it as next to impossible "to work undisturbed without reliance on criminals."2

The experience of the Swedish Police is that "the threshold of using violence against the police has fallen over the past ten years. ${ }^{3}$ This is exemplified by a number of spectacular bombings against the Swedish Police, both at the precinct and outside the residences of top police officers, as well as by the reckless use of hand grenades in gang fights, and innocent children being killed by the explosions. ${ }^{4}$ The disinclination to participate in lawsuits becomes understandable in light of this criminal audacity and recklessness. As editor of the Swedish magazine Kvartal Paulina Neuding puts it, "the kind of social contract between state and society that leads citizens to help the authorities is not working in those parts of Sweden where the police is seen as the enemy."

The Swedish Police's denomination of "vulnerable areas," and the problems they face, have given rise to the term "no-go zones." First used by the rightwing commentator Per Gudmundson, ${ }^{6}$ it is not a concept advocated by the Swedish Police, but it has turned into a relatively accepted, albeit controversial, metaphor to describe "vulnerable areas" among rightwing opinion makers. More so, and apart from criminal attacks against the police, the Chairman of the Swedish Ambulance Drivers Union, Gordon Grattidge, claims that no-go zone indeed is the proper concept to use since medics often cannot enter vulnerable areas without police protection. $^{7}$

Even if no-go zone is not an officially endorsed concept nor articulated by mainstream politicians, politicians from the Left and the Right alike are nonetheless concerned about crime spiraling out of control, and the political issue of law and order was significant ahead of the 2018 general election. When Ulf Kristersson assumed his position as the new party leader of the liberal-conservative Moderate Party, he stated in his inauguration speech that the number one priority of the party

\footnotetext{
2 Ibid, p. 10, 4.

3 Ibid, p. 29.

${ }^{4}$ Ibid, p. 26-28, 38; see also, Paulina Neuding, "Violent Crime in Sweden Is Soaring. When Will Politicians Act?", The Spectator, 10 Feb. 2018, https:// www.spectator.co.uk/2018/02/violent-crime-in-sweden-is-soaring-when-willpoliticians-act/ (accessed 19 Aug. 2018).

5 Ibid.

6 Per Gudmundson, "55 'no go'-zoner i Sverige” [“55 'no go'-zones in Sweden”], Svenska Dagbladet, 28 Oct. 2014, https://www.svd.se/55-no-gozoner-i-sverige (accessed 19 aug 2018).

${ }^{7}$ Stated in DGS TV. Gäster: Per Brinkemo Och Gordon Grattidge: Våld Mot Ambulanspersonal [Guests: Per Brinkemo and Gordon Grattidge: Violence against Ambulance workers], https://www.youtube.com/watch?v= dOXN2BHLDDo (accessed 19 aug 2018).
}

should be to restore the authority of the state. Kristersson said, "crime is a tumor" that must to be eliminated and that few tasks are as acute as the one to crush the gangsters that terrorize cities and suburbs. According to Kristersson, certain parts of Sweden are "lawless." ${ }^{8}$ Social democratic Prime Minister Stefan Löfven is of the same opinion. "Organized crime," Löfven said before tripping on the question if he is willing to use the military to fight the gangs, "is a poison in our society that has to go away." A message he repeated in his 2017 Christmas speech:

We have crime that is scary and completely unacceptable... Violence spreads fear. It increases the insecurity and it restricts people's freedom. It makes us hesitate, about where we should live, where to walk, how to live. Those who are affected are common people: aspiring fellows often a little further down the social ladder. We can never accept that. ${ }^{10}$

This understanding led both the Social Democrats and the Moderates - the two biggest parties in Sweden - to elevate law and order as one of their core electoral issues. In relation to a presently unfolding debate about the link between certain type of crime and immigration, both the Social Democrats and the Moderates have responded with "a kind of tough talk that would have been deemed xenophobic, or worse, in mainstream discourse only a few years ago." "The far-right nationalist party the Sweden Democrats, whose popularity has risen exponentially in recent years and is now Sweden's third biggest party, has long warned that law and order is deteriorating, a problem it connects to immigration. In contrast to the other political parties in the Swedish parliament, the Sweden Democrats has no problem using the concept no-go zone and claims that the other parties are merely copying its long-held political agenda when they are becoming tough on crime.

National data from the Swedish National Council for Crime Prevention informs us that while deadly crime is on a downward trajectory since the 1980 s, the level of gang-

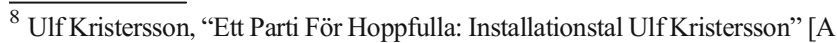
party for the hopeful: Inauguration speech Ulf Kristersson] 1 Oct. 2017, http:// cdn.moderat.se/caa7af5f-d184-4272-93a4-7601c3334819/Documents/tal-ulfkristersson-171001.pdf (accessed 19 Aug. 2018).

${ }^{9}$ Aftonbladet TV. Löfven utesluter inte militär mot gängen [Löfven does not rule out the military against the gangs], 17 Jan. 2018, https://www.aftonbladet. se/a/L01m3J (accessed 19 Aug. 2018).

${ }^{10}$ Stefan Lövén, “Jultal 2017”' [Christmas speech 2017], 17 Dec. 2017, https:// www.socialdemokraterna.se/vart-parti/politiker/stefan-lofven/tal3/tal-2017/ jultal-2017/ (accessed 10 Aug. 2018).

${ }^{11}$ Paulina Neuding, "Sweden's General Election Turmoil." Quillette, 7 Sept. 2018, https://quillette.com/2018/09/07/swedens-general-electionturmoil/ (accessed 10 Sept. 2018).
} 
related, deadly street violence is on the rise, ${ }^{12}$ including driveby shootings and hand grenade attacks, something the Swedish Police argues is without parallel in contrast to other comparable countries. ${ }^{13}$ In terms of shootings, 2018 was a record year for Sweden with 44 killings. According to a report by the Swedish Institute for Futures Studies, the Swedish antagonistic milieu - an umbrella term for organized-crime and violent-extremist networks - comprises 15,244 individuals covering different organizational types, such as motorcycle gangs, which organize the biggest proportion of individuals, but also looser criminal networks, violent Islamic extremism, white-power groups, left-wing autonomous movements and football firms. ${ }^{14}$ Crime also seems to be a great concern for the general Swedish populace. In a recent poll conducted by Ipsos, $50 \%$ of the Swedish respondents stated that they worried about crime and violence, a unique position for a country like Sweden. Among the countries surveyed, only Peru (67\%), Mexico (63\%), Chile (59\%) and South Africa (59\%) showed worse results than Sweden whose population surprisingly worry more about crime and violence than populations in Brazil (47\%), India (38\%), and US (29\%). ${ }^{15}$ The SOM Institute show that $17 \%$ of the Swedish population rank law and order as one of the most important problems in Swedish society (occupying the 4 th place). ${ }^{16}$ This figure indicates a rebounding from a previous low at the turn of the decade.

Gang crime and shootings have become robust plots in an alternative story that challenges the exceptionalist narrative of Sweden as a peaceful and "safe" welfare state. At the same time, the Swedish Police is struggling. Recruitment is difficult, salary levels are low and the pains of a recent large-scale administrative reorganization are still being felt, and this as the police is facing ever more audacious and ruthless criminals. Many parts of Sweden face a greatly

\footnotetext{
$\overline{12}$ Brottsförebyggande rådet (BRÅ). Brottsutvecklingen i Sverige Fram till År 2015 [Crime development in Sweden until year 2015], Stockholm 2017, pp. $50,58,64,259, \mathrm{https://www.bra.se/download/18.}$ 4a33c027159a89523b1ae6a8/1494921154159/2017 5 Brottsutvecklingen i Sverige fram till_ar_2015.pdf (accessed 19 Aug. 2018).

${ }^{\overline{1}}$ Hanna Björnheden, "Ökningen av granater saknar motstycke" [The increase of grenades is unprecedented], Göteborgs-Posten, 25 Aug. 2016, http://www.gp.se/1.3727983 (accessed 10 Aug. 2018); Diamant Salihu, "116 granatattacker på åtta år - Sverige sticker ut" [116 grenade attacks in eight years - Sweden stands out], SVT Nyheter, 10 Dec. 2018, https://www.svt.se/ nyheter/inrikes/116-granatattacker-pa-atta-ar-sverige-sticker-ut?cmpid=del: tw:20181210:116-granatattacker-pa-atta-ar-sverige-sticker-ut:nyh:lp (accessed 11 Dec. 2018).

${ }^{14}$ Amir Rostami, Hernan Mondani, Christoffer Carlsson, Joakim Sturup, Jerzy Sarnecki, Christofer Edling, "Våldsbejakande extremism och organiserad brottslighet i Sverige" [Violent extremism and organized crime in Sweden], Forskningsrapport, 2018/4, Institutet för framtidsstudier, Stockholm, https:// www.iffs.se/media/22498/brott 2018 4.pdf (accessed 1 Dec. 2018).

${ }^{15}$ Ipsos, What Worries the World - July 2018, 6 Aug. 2018, https://www.ipsos. com/en/what-worries-world-july-2018 (accessed 19 Aug. 2018).

16 Johan Martinsson \& Ulrika Andersson (eds.), Svenska Trender 1986-2017 [Swedish Trends 1986-2017], SOM Institutet, Göteborgs universitet, https:// som.gu.se/digitalAssets/1693/1693084_1.-svenska-trender-1986-2017.pdf (accessed 1 Dec. 2018), p. 41
}

undersized police presence, giving rise to reports about lawlessness or cities that "the law abandons." 17 The plight of the Swedish Police has become commonplace: "The police is in crisis." 18

Law and order might very well be regarded as a peripheral issue which only concerns small pockets of Swedish society, yet when "crime is a tumor" it affects "common people," as articulated by the mainstream politicians themselves. At the same time, critics are Janus-faced. On the one hand, the crime image of Swedish cities like Malmö is disputed because it is used to disapprove of the multicultural society, ${ }^{19}$ but on the other hand, critical voices argue that Sweden is becoming a "police state," infused with brutality and racial profiling of immigrant residents. ${ }^{20}$ Either we should ignore to tell the truth about cities affected by crime because it serves the "wrong" political forces or we should exaggerate it. None is tenable. Instead, we need to talk about crime for what is, wherever it is. The story about Sweden as a safe and peaceful welfare state is contested because the challenge of crime is real - whether organized crime, gang crime, or hate crime.

\section{Dysfunctional Institutions and Parallel Social Structures}

Swedish institutions are malfunctioning, at least to judge by a number of prominent scandals. Here are a few examples. The Swedish Transport Agency mistakenly allowed classified information to become available to foreign non-security personnel when the IT system was outsourced to Eastern Europe, leading to Constitutional Committee hearings and ministerial reshuffling. At the Swedish National Audit Office the three Auditors Generals were accused of nepotism, leading to a scandal were all three resigned, followed by investigations that confirmed that they had violated the Swedish Audit Act.

\footnotetext{
${ }^{17}$ Jesper Nilsson, "En polisbil täcker hela södra Lappland" [One police car covers the whole of Southern Lappland], SVT Nyheter, 21 Sept. 2017, https:// www.svt.se/nyheter/lokalt/vasterbotten/kammarrattens-beslut-en-polisbil-skatacka-sodra-lappland (accessed 19 Aug. 2018); P-O, Nilsson, "Staden som lagen har övergivit" [The city the law has abandoned], Dagens Industri, 4 Feb. 2018. https://www.di.se/ledare/staden-som-lagen-har-overgivit/ (accessed 19 Aug. 2018).

${ }^{18}$ Svenska Dagbladet, "Polisens kris" [Police crisis] https://www.svd.se/om/ polisens-kris (accessed 19 Aug. 2018); Dagens Nyheter, "DN granskar: Polisens kris" [Police crisis] https://www.dn.se/om/dn-granskar-polisens-kris/ (accessed 19 Aug. 2018); Aftonbladet, "Krisen inom polisen" [Crisis within the Police], https://www.aftonbladet.se/story/88436140-2378-4677-a7a1dflaf737adf6 (accessed 19 Aug. 2018).

${ }^{19}$ Leandro Schclarek Mulinari. "Contesting Sweden's Chicago: Why Journalists Dispute the Crime Image of Malmö." Critical Studies in Media Communication 34, no. 3 (2017), pp. 206-19.

${ }^{20}$ See, "Polisstat i Sverige? Nej tack" [Police state in Sweden? No thanks], Aftonbladet, 22 Feb. 2013, https://www.aftonbladet.se/a/m63xmE (accessed 29 Sep 2018); "Reva fortsätter underminera Sverige som rättsstat" ["Reva" continues to undermine the rule of law of Sweden], Expressen, 15 Feb 2014, https://www.expressen.se/debatt/reva-fortsatter-underminera-sverige-somrattsstat/ (accessed 29 Sep 2018).
} 
The Swedish Maritime Administration violated several laws and regulations in a recent deal with an Italian helicopter manufacturer. And the construction of the New Karolinska University Hospital in Stockholm has been plagued by gross mismanagement and is coined "the world's most expensive hospital," not for the right reasons, but for disbursing hundreds of millions on needless consultants.

The blatant misuse of Swedish taxpayer funds, the senseless outsourcing of government services, administrative misconduct, unlawful behavior, and the nepotism among top civil servants paint a grim picture of Swedish bureaucracy.

Furthermore, the problems that have plagued the Swedish Migration Board are too numerous to be briefly recounted, and what Swedes consider problematic depend on their political affiliation given the fact that immigration has become such a loaded political issue. Prevention of deportations is one man's crime, and another man's civil disobedience. Yet suffice to mention, at the height of the 2015 migration crisis, when Sweden received the highest number of immigrants per capita in Europe, the Swedish Foreign Minister Margot Wallström said, if the current level of immigration continues, "in the long run, our systems will collapse." It throws light on the perceived lack of capacity of the Migration Board, and of Swedish society in general, to handle the inflow of immigrants without serious effects on Sweden's welfare state model.

The social workers acutely feel these effects, especially the burden that has come with the large influx of unaccompanied minors. Even before the 2015 "migration crisis", only a small minority of Swedish social workers claimed they were able to follow the rules and regulations of the National Board of Health and Welfare, and their work situation was described as "alarming." 21

If we look at the 2015 PISA results, Sweden reached 24th place in math, 28th place in science, and 17th place in reading, far away from the top scoring Asian and European countries. "A national crisis," according to Stefan Löfven. ${ }^{22}$ According to Swedish scholars, the problem is that postmodern, socialconstructivist thought permeates the Swedish school system. $^{23}$

Before the 2014 general election, as the Social Democrats was presenting its election manifesto, then to become Prime Minister Stefan Löfven claimed, "Sweden is breaking apart,"

\footnotetext{
${ }^{21}$ Jens Mikkelsen, "Socialtjänsten går på knäna" [The social service is on its knees], Sydsvenskan, 8 April 2013, https://www.sydsvenskan.se/2013-04-08/ socialtjansten-gar-pa-knana (accessed 1 Sep. 2018).

22 Quoted in Jens Kärrman, "Löfven om Pisa: Nationell kris" [Löfven about Pisa: National Crisis], Dagens Nyheter, 3 Dec. 2013, https://www.dn.se/ nyheter/sverige/lofven-om-pisa-nationell-kris/ (accessed 29 Sep. 2018).

${ }^{23}$ Magnus Henrekson, Inger Enkvist, Martin Ingvar, Ingrid Wållgren, Kunskapssynen och pedagogiken [Knowledge and pedagogy], Dialogis Förlag, 2017; Magnus Henrekson and Johan Wennström, "'Post-Truth' and the Decline of Swedish Education" Quillette, 18 Sep. 2018, https:/quillette. com/2018/09/18/post-truth-and-the-decline-of-swedish-education/ (accessed 29 Sep 2018).
}

while highlighting the traditional welfare issues of health care, education, unemployment, and inequality. In terms of economic inequality, Swedish wealth distribution is on par with countries like Brazil and the United States, representing the most unequal pattern in Western Europe, while income distribution is back to levels Sweden had in the 1940s. ${ }^{24}$ But the fact that the Social Democratic Party is responsible for many of the policy changes that have rolled back the traditional welfare state and infused Swedish bureaucracy with a "new public management" regime makes Löfven's concern sound hollow. When few dare to question or change the economistic logic of Swedish public institutions, the problems will unfortunately remain. ${ }^{25}$ Even so, despite scandals and problems, the Swedish population's trust in public institutions remain fairly high and stable. ${ }^{26}$

Another challenge relates to the emergence of "parallel social structures". According to the report by the Swedish Police referred to above, "specifically vulnerable areas" face problems with parallel social structures that limit people's, in particular women's, rights and freedoms. Politicians and commentators that refer to this problem mostly belong to the Right, but even politicians from the Left articulate these concerns. For instance, Left Party parliamentarian Amineh Kakabaveh has repeatedly claimed that self-proclaimed Islamic moral police try to control girls and women in immigrant neighborhoods. ${ }^{27}$ Civil society representatives describe Sweden as "a paradise for honor culture," 28 referring to a spectrum of repressive actions conducted in the name of honor. Former social democratic parliamentarian Nalin Pekgul and former social-democratic chairperson of the Gothenburg municipality Ann-Sofie Hermansson, who long have fought against honor oppression, give an insightful depiction of the Swedish political situation:

Looking back on what has been done since [the 1990s], the horizon is gloomy. It took a long time before Sweden even dared to acknowledge the fact that honor oppression exists. There are many who stayed silent, when they should have spoken. There are many who awaited,

\footnotetext{
${ }^{24}$ Göran Therborn, "Twilight of Swedish Social Democracy", New Left Review 113, Sep/Oct 2018, pp. 5-26.

${ }^{25}$ Lennart Lundquist. "Tystnadens förvaltning" [The Silent Administration] in Utan fast punkt. Om förvaltning, kunskap, språk och etik $i$ socialt arbete. Socialstyrelsen, 2001; I D. Rauhut, \& G. Adamson (eds.) Kejsarens nya kläder: om New Public Management och de svenska universitetens sönderfall [The Emperor's New Clothes: New Public Management and the Decomposition of Swedish Universities], Academic Rights Watch, 2018.

26 SOM Institutet, op. cit., pp. 4-10.

27 Amine Kakabaveh, "DEBATT: Utfryst - efter att jag talade om hedersvåld" [DEBATE: Ostracized - after I spoke of honor violence], Aftonbladet, 29 Nov. 2017, https://www.aftonbladet.se/debatt/a/Xwwx37/utfryst\%2D\% 2Defter-att-jag-talade-om-hedersvald (accessed 1 Sep. 2018).

${ }^{28}$ Maria Rashidi, Maria, Samiran Ishak, and Meheret Dawit. "DEBATT: Sverige - ett paradis för hederskulturer" [DEBATE: Sweden - a paradise for honor culture], Aftonbladet, 16 Okt. 2016, https://www.aftonbladet.se/a/ 0EbRM2 (accessed 1 Sep. 2018)
} 
when they should have acted... It has also been difficult to see a political left who did not dare to speak plainly about the existence of honor oppression... There has been a fear of being stamped as racist or Islamophobic. ${ }^{29}$

The exact number of how many people that experience oppression in the name of honor is uncertain, yet official state reports put the number somewhere around $70,000 .{ }^{30} \mathrm{An}$ article in the daily newspaper Aftonbladet, citing researcher Astrid Schlytter, stated that up to 240,000 young people are restricted by honor culture. ${ }^{31}$ This figure has also been mentioned in political debates.

Parallel social structures does not only concern honor culture or self-proclaimed Islamic moral police, but also the existence of clan-based parallel court systems, as certain immigrants bring their customary legal systems to Sweden. ${ }^{32}$ In any case, the enclave is challenging the Swedish state. ${ }^{33}$

The above points to "the integration problem" as Sweden's "ticking bomb," in the words of Ulf Kristersson, or "Sweden's biggest challenge,"34 as articulated by the Liberal Party leader Jan Björklund. However, the issue of integration has long been understood in terms of the concept of "social exclusion,"35 which mainly was defined as a problem of immigrant unemployment, and by extension a language issue. That integration now is also understood as a cultural issue, and connected to the notion of "parallel social structures," is indicative of a discursive change that gained momentum after the 2015 migration crisis. ${ }^{36}$

\footnotetext{
${ }^{29}$ Nalin Pekgul, and Ann-Sofie Hermansson. "DEBATT: Hedersförtrycket har fått pågå alltför länge" [DEBATE: honor oppression has been going on for too long], Aftonbladet, 3 Feb. 2018, https://www.aftonbladet.se/a/WLjb7L (accessed 1 Sep. 2018).

${ }^{30}$ Ungdomsstyrelsen, Gift mot sin vilja [Married against one's will], 2009; Nationell strategi mot mäns våld mot kvinnor och hedersrelaterat våld och förtryck [National strategy against men's violence against women and honorrelated violence and oppression], SOU 2015:55.

${ }^{31}$ Joachim Kerpner, and Lisa Röstlund. "Forskare: 240000 unga i Sverige kan vara drabbade" [Researcher: 240000 young people in Sweden can be affected], Aftonbladet, 29 May, 2017, https://www.aftonbladet.se/nyheter/a/knnm9/ forskare-240-000-unga-i-sverige-kan-vara-drabbade (accessed Sep. 42,018).

32 Per Brinkemo, Mellan klan och stat: somalier i Sverige [Between clan and state: Somalis in Sweden], Timbro, 2015.

${ }^{33}$ For an early perspective on the emergence of parallel social structures, see Aje Carlbom, "Enklaven utmanar nationalstaten" [The enclave challenges the nation-state], Axess, Vol. 4, 2005, pp. 31-34.

${ }^{34}$ Sveriges Radio, "Björklund: Integrationen största utmaningen" [Björklund: Integration the biggest challenge], 23 April 2016, https://sverigesradio.se/sida/ artikel.aspx?programid=83\&artikel=6417851 (accessed 10 Sept. 2018); See also the Liberal Party's integration program: "Stärk individen och motverka parallellsamhällen" [Strengthen the individual and counteract parallel societies], https://www.liberalerna.se/wp-content/uploads/integrationsprogram lib1.pdf (accessed 10 Sept. 2018).

${ }^{35}$ This refers to the Swedish concept "utanförskap." The "vulnerable areas" are also called "utanförskapsområden" in Swedish.

${ }^{36}$ A search in the Swedish media archive Retriever reveal a tenfold increase in hits for the key words "parallella samhällen", "parallellsamhälle", and "parallella samhällsstrukturer" since 2014. From 46 hits in 2014 to 548 hits in 2017 for "parallella samhällen"; from 73 hits in 2014 to 664 hits in 2017 for "parallellsamhälle"; from 1 hit in 2014 to 680 hits in 2017 for "parallella samhällsstrukturer".
}

Instead of a socially integrated harmonious society, the emergence of parallel social structures further weakens Swedish statehood and highlights the challenges of segregation and fragmentation. It relates to the emergence of an ethnic underclass that risks being drawn into these parallel structures when formal employment is lacking. "If there is anything I worry about," Ann-Sofie Hermansson says, "then it is parallel structures in society.",37

\section{The Struggle for the Remaking of the Swedish Nation}

Following Liah Greenfeld, nationalism defines the idea of the modern state. Nationalism is the cultural framework of the modern world - the consciousness and vision of reality that has come to shape the idea of the state up until this day. Greenfeld argues that there are three types of nationalism: individualistic/civic, collectivistic/civic, and collectivistic/ ethnic types of nationalism.

The individualistic/civic type of nationalism views the nation as a composite entity made up of individuals considered free and equal. In principle, one does not have to "buy into" any particular cultural framework to become a member of the nation. This is the foundation of Western liberal democracy, and the United States, with its unrestricted jus soli or birthright citizenship, exemplifies this type of nationalism. In the United States, persons join an individualist culture, not an American culture. People from all over the world are free to choose their identities - whatever their creed - without the state telling people how to behave to become American. The collectivistic/civic type of nationalism views the nation as a collective individual with its own unique will, characteristics, and interests - its own culture. Although one might have acquired citizenship, the nation has a unique culture that one needs to "buy into" in order to gain full membership in the nation. Here France serves as the archetype, and if one, for instance, does not "buy into" the principle of laïcité, as exemplified by the prohibition of religious apparel in public schools, one is not fully French. Finally, the collectivistic/ ethnic type of nationalism is defined by blood - jus sanguinis. While membership in the individualistic/civic and collectivistic/civic types of nationalism is, in principle, voluntary, membership in the collectivistic/ethnic type of nationalism is connected to a primordial or genetic link to the nation. In this way, the collectivistic/ethnic type of nationalism is indeed a form of racism, which makes it very hard, in principle impossible, to join the nation without blood ties. It is thus also

\footnotetext{
${ }^{37}$ Cited in interview with Adam Cwejman, "Hermansson: 'Om det är något jag oroar mig över så är det parallella strukturer i samhället." [Hermansson: 'If there is anything I worry about then it is parallel structures in society'] 30 Aug. 2018, Göteborgs-Posten, http://www.gp.se/1.7946436 (accessed Sept. 10, 2018).
} 
the most intolerant and aggressive type of nationalism. Historically, this type of nationalism first developed in Russia, then in Germany, before it spread to Japan, China, and the rest of the world. ${ }^{38}$

Sweden is experiencing an ongoing struggle to define the nation. Swedish nationalism long incorporated elements of the collectivistic/ethnic type of nationalism. The world's first state institute for the study of eugenics, the National Institute for Racial Biology, was established at Uppsala University in 1922. During the interwar period, the national narrative depicted the Swedish people as "racially superior." The Swedish people was seen as belonging to "an especially pure and great race and that people of 'inferior blood' did not possess the same excellent qualities as the Swedes." 39

After the Second World War, however, the collectivistic/ ethnic type lost its appeal for obvious reasons, although it never disappeared. Instead, by the 1960 s, Sweden was portrayed as a progressive and modern nation with "a nationalistic self-image of Swedes as one of the most, if not the most, enlightened people in the world." ${ }^{40}$ In the 1970s, Sweden embraced multiculturalism. As historian Mats Wickström puts it, "The new public ideal of multiculturalism included a normative rejection of what was, and is, conceptualized as its opposite; the ideal of homogeneity and all the social and political ills that are perceived to steam from this ideal, e.g. assimilationist policies." 41 At the same time, Sweden embraced immigration, first labor-force immigration, and then refugees and asylum-seekers from all over the world.

This development can be interpreted differently. One could view it in terms of the individualistic/civic type of nationalism, but the fact is that multiculturalism was never a matter of individual choice, even though the Swedish population has become increasingly individualist and American in its "flair". A more accurate way to look at multiculturalism is that it was a product of social engineering, of molding the public opinion through the instruments of policy, media discourse, and the education system. ${ }^{42}$ It was a matter of transforming Sweden into a new, modern heterogeneous collective individual; a collectivistic/civic nationalist project that imposed multiculturalism as the new ideological superstructure. Conceiving it from this perspective resonates well with Sweden's long-held tradition of corporatist consensus-building, yet one can also view the multicultural ideal, perhaps counterintuitively, from a collectivistic/ethnic perspective with a twist; that is, in the

\footnotetext{
${ }^{38}$ Liah Greenfeld, Nationalism: Five Roads to Modernity, Harvard University Press, 1993

${ }^{39}$ Mats Wickström, "Making multiculturalism work: policy and praxis on moulding attitudes and public discourse on ethnic diversity in post-war Sweden," NORDEUROPAforum (2014), p. 14.

${ }^{40}$ Ibid, p. 26.

${ }^{41}$ Ibid, p. 15.

${ }^{42}$ Ibid.
}

form of "benign" ethnic or religious group identities and rights. Instead of an ethnically homogenous nation, we now have a nation composed, not of individuals, but of several small ethnic or religious groups living side by side. This ethnic diversity was cherished and promoted, again, with the help of the state. Such a perspective would further resonate with Eric Kaufmann's concept of "asymmetric multiculturalism," which captures how minority ethnic groups are encouraged to maintain and promote their idiosyncratic group identities and interests while the majority group is dissuaded from pursuing the same practice. ${ }^{43}$

However we make sense of it, the new multiculturalist framework that took root during the 1970s became Sweden's new ideological superstructure, and for a long time, it stood without being seriously challenged. In the process, "Swedishness" or Swedish values became taboo in a public discourse that celebrated cosmopolitanism and "otherness." As former social democratic Minister of Integration, Mona Sahlin, put it: "I cannot figure out what Swedish culture is. I think that is part of what make many Swedes so jealous of immigrant groups. You have a culture, an identity, a story, something that binds you. And what do we have? We have Midsummer Eve and such 'dorky' things." "44 And while rejecting Swedish communitarian bonds as trivial or geeky, Sahlin highlighted the cosmopolitan values of democracy, equality, and human rights. Sweden's former liberalconservative Prime Minister, Fredrik Reinfeldt, articulated the same message in an equally astonishing way: "Only barbarism is genuinely Swedish. All further development has come from abroad." ${ }^{45}$ While the enlightened political elite bashed Swedishness, they portrayed Sweden as a tolerant, immigrant-friendly, outward-looking, internationalist state committed to spread cosmopolitan values at home and abroad. Politicians with different party affiliations all embraced immigration and reverberated the same message: "open your hearts," "my Europe does not build walls." World citizens unite!

However, the 2015 migration crisis struck a definite blow against this discourse. Voices among the Swedish political and intellectual elite - from the Left and the Right alike - have come to accept, at least tacitly, parts of the critique against immigration and multiculturalism raised by the far-right nationalist party the Sweden Democrats. As a result, a political struggle for the remaking of the Swedish nation is now gathering storm.

\footnotetext{
${ }^{43}$ Kaufmann, Eric P. The Rise and Fall of Anglo-America. London: Harvard University Press, 2004.

${ }^{44}$ Quote taken from interview in the Swedish magazine Euroturk, March 2002, pp. 10-15.

${ }^{45}$ Dagens Nyheter, "Reinfeldt: Det ursvenska är blott barbari" [Reinfeldt: Only barbarism is genuinely Swedish] 15 . Nov. 2006, https://www.dn.se/ nyheter/politik/reinfeldt-det-ursvenska-ar-blott-barbari/ (accessed 1 Sep. 2018).
} 
As it has become increasingly popular, the Sweden Democrats has suppressed the ethnic element in its nationalist rhetoric ${ }^{46}$ and moved towards a hard-line collectivistic/civic type of nationalism that emphasizes non-negotiable requirements of cultural assimilation in order to gain citizenship and full membership in a homogenous Swedish nation. At the same time, statements that resemble an increased affinity for this type of homogenous collectivistic/civic nationalism have become commonplace among mainstream politicians, which in fact indicate a rhetorical move away from multicultural diversity. For instance, when prominent Green Party member Yasri Khan refused to shake hands with a female reporter by referring to his Muslim faith, a heated discussion erupted that made former Prime Minister Stefan Löfven intervene. Löfven's intervention, in a parliamentary debate, perfectly summarized the dominant sentiment: "In Sweden we greet each other; we shake hands with both women and men." Gone is the embrace of diversity. The liberal conviction that individuals choose their own ethical mores is sidelined and respect for religious and ethnic group identities is shelved.

From being nonexistent, geeky, and barbaric, Swedish values now form the basis of a "new conservatism" that has started to penetrate the political mainstream. Swedish parties are waving flags like never before, competing about who is the most Sweden-friendly party and how to define Swedish values. ${ }^{47}$ During the 2015 migration crisis, the social democratic-led government imposed border controls and became tough on immigration, something social democratic election propaganda legitimized as necessary to protect "the Swedish model". ${ }^{4}$

While the homogenous collectivistic/civic type of nationalism represents a significant rhetorical current in the debate about Swedish nationalism, it is by no means hegemonic. During a 2018 election debate, while asked if they support multiculturalism, all parties but the Sweden Democrats and the Christian Democrats responded yes. And while liberals balk at the notion that individuals have to accept certain cultural frameworks, even though many recognize the importance of language, left-wing politicians and activists advocate a strand of "benign" identity politics. Since structural racism, white privilege, and sexism supposedly permeate mainstream society according to these left wing voices, vulnerable groups must separate and create their own exclusive safe spaces.

\footnotetext{
${ }^{46}$ Party representatives certainly still harbors the collectivistic/ethnic type of nationalism, and many famous scandals keep on revealing that. After all, Sweden Democrats is a party with neo-Nazi roots. Yet it will never be able to gain a foothold in Swedish politics by emphasizing the ethnic element publicly.

47 SVT Nyheter, "Svenska värderingar för politikerna" [Swedish values according to the politicians] 16 Dec. 2017, https://www.svt.se/nyheter/inrikes/ svenska-varderingar-for-politikerna (accessed 2 Sept. 2018).

${ }^{48}$ Mikael Feldbaum, "S-Annons Solkar Ner Den Svenska Modellen" [Sadvertisment dirt down the Swedish model], Arbetsvärlden, https://www. arbetsvarlden.se/ledare/s-annons-solkar-ner-den-svenska-modellen/ (accessed 2 Sept. 2018)
}

Therefore, at the same time as social democratic Prime Minister Stefan Löfven claims that "in Sweden we shake hands," the social democratic youth league SSU arranges meetings that exclude white people. ${ }^{49}$

Since 1990, polls have consistently indicated that a significant plurality and at times a majority of the Swedish population want to receive less refugees, ${ }^{50}$ and this while Swedish governments have implemented opposite policies. This political disconnect is no longer viable. Since 2015, immigration has been the single most important political issue in Sweden, ${ }^{51}$ and a new policy paradigm has emerged that acknowledges that Sweden needs to reduce the level of immigration. ${ }^{52}$ At the same time, according to a 2017 opinion poll by Pew Research, Swedes scored the lowest on the nationalist, anti-immigrant, anti-religious minority attitudes (NIM) scale. ${ }^{53}$ From this vantage point, Swedes are generally tolerant, but they want reduced and managed migration, and some want to be able to express love for their communities and Swedish way of life because they cherish that they belong "somewhere". 54

The issue at stake is more than a struggle over the regulation of immigration; it is a political struggle about the remaking of Swedish nation itself. Since the individualistic/civic, collectivistic/civic, and collectivistic/ethnic types of nationalism provide different foundations for the regulation of immigration, this struggle inevitably comes first. It is a question about what type of nationalism Sweden should have. For a country with a long history of collectivistic/ethnic nationalism together with a long tradition of corporatist regulation of social life, sustained flows of large-scale immigration was bound to generate some sense of ethno-cultural anxiety. ${ }^{55}$ After all, one could argue that all nations have both a civic and an ethnic component, which highlights the ideal-typical tension embedded in Greenfeld's types of nationalism. Thus, even for a liberal, a discussion of limits to immigration - for long a taboo topic in Sweden - can be seen as appropriate to stave off illiberal sentiment and to uphold an individualistic/civic type of nationalism.

The parliamentary deadlock, the pariah status of the Sweden Democrats, and the split of the centre-right liberalconservative "Alliance", epitomized by the Centre Party's

\footnotetext{
$\overline{49}$ Rebecca Weidmo Uvell, "Debattartikel: 'Vita - inte önskvärda här!'” [Debate article: 'Whites - not desirable here!'] SVT Nyheter, 8 Sept. 2016, https://www. svt.se/opinion/rebecca-weidmo-uvell-om-ssu (accessed 2 Sept. 2018).

${ }^{50}$ SOM Institutet, op. cit., p. 47.

${ }^{51}$ Ibid, p. 41.

${ }^{52}$ Henrik Emilsson, "Continuity or Change? The Refugee Crisis and the End of Swedish Exceptionalism." MIM Working Paper Series; 18/3, 2018.

${ }^{53}$ Jeff Diamant \& Kelsey Jo Starr, "Western Europeans vary in their nationalist, anti-immigrant and anti-religious minority attitudes", Pew Research Center, 19 Jun. 2018, http://www.pewresearch.org/fact-tank/2018/06/19/ western-europeans-vary-in-their-nationalist-anti-immigrant-and-antireligious-minority-attitudes/ (accessed 4 Dec. 2018)

${ }^{54}$ David Goodhart, The Road to Somewhere: The Populist Revolt and the Future of Politics. London: Hurst, 2017.

${ }^{55}$ I am grateful to Carl Ritter for suggesting the concept of ethno-cultural anxiety.
} 
hardcore liberal stance, is primarily about nationalism. The question about what type of nationalism Sweden should have remains to be answered.

Acknowledgements The author would like to express his sincere gratitude to Carl Ritter, Johan Modee, Salvatore Babones, Scott Mciver, Aje Carlbom, Erik Ringmar and Björn Jerden for comments on earlier drafts.

Open Access This article is distributed under the terms of the Creative Commons Attribution 4.0 International License (http:// creativecommons.org/licenses/by/4.0/), which permits unrestricted use, distribution, and reproduction in any medium, provided you give appropriate credit to the original author(s) and the source, provide a link to the Creative Commons license, and indicate if changes were made.

Publisher's Note Springer Nature remains neutral with regard to jurisdictional claims in published maps and institutional affiliations.?

John H. S. Åberg is a senior lecturer in the Department of Global Political Studies at Malmö University, Sweden. He has previously published in Global Asia, Conflict Trends, and Contemporary Chinese Political Economy and Strategic Relations. You can reach him@JHSaberg on Twitter. 